Proc. of the X Int. Conf. - Ion Implantation and other Applications of Ions and Electrons, Kazimierz Dolny 2014

\title{
Investigation of $\mathrm{NbN}$ and $\mathrm{Nb}-\mathrm{Si}-\mathrm{N}$ Coatings Deposited by Magnetron Sputtering
}

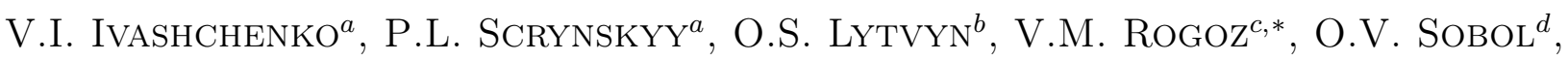 \\ A.P. KuZmenko ${ }^{e}, \mathrm{H}$. Komsta ${ }^{f}$ And C. Karvat ${ }^{g}$ \\ ${ }^{a}$ Institute for Problems of Material Science, NASU, Krzhyzhanovsky Str. 3, 03680 Kiev - 142, Ukraine \\ ${ }^{b}$ Institute of Semiconductor Physics, NASU, Nauky Pr. 41, 03028 Kyiv, Ukraine \\ ${ }^{c}$ Sumy State University, Rimsky-Korsakov Str. 2, 40000, Sumy, Ukraine \\ ${ }^{d}$ National Technical University "Kharkiv Polytechnic Institute", Frunze Str. 21, 61002, Kharkov, Ukraine \\ ${ }^{e}$ Kursk State Technical University, Center for collective use "High Tech", \\ 305040, October 50 Str. 94, Kursk, Russia \\ ${ }^{f}$ Institute of Transport, Combustion Engines and Ecology, Lublin University of Technology, \\ Nadbystrzycka 36, 20-618 Lublin, Poland \\ ${ }^{g}$ Department of Electrical Devices and High Voltage Technology, Lublin University of Technology, \\ Nadbystrzycka 36, 20-618 Lublin, Poland
}

\begin{abstract}
$\mathrm{NbN}$ and $\mathrm{Nb}-\mathrm{Si}-\mathrm{N}$ films were deposited by magnetron sputtering the $\mathrm{Nb}$ and $\mathrm{Si}$ targets on silicon wafers at various bias voltages, $U_{s}$. The deposited films were annealed to establish their thermal stability. The films were investigated by atomic force microscope, X-ray diffraction, X-ray photoelectron spectroscopy and nanoindentation. The NbN films were nanostructured, and the $\mathrm{Nb}-\mathrm{Si}-\mathrm{N}$ films had a nanocomposite structure, and represented an aggregation of $\delta-\mathrm{NbN}_{x}$ nanocrystallites embedded into the amorphous $\mathrm{Si}_{3} \mathrm{~N}_{4}$ tissue $\left(\mathrm{nc}-\delta-\mathrm{NbN} \mathrm{N}_{x} / \mathrm{a}-\mathrm{Si}_{3} \mathrm{~N}_{4}\right)$.
\end{abstract}

DOI: 10.12693/APhysPolA.128.949

PACS: 61.05.C-, 61.05.cp, 68.37.Ps, 61.05.js

\section{Introduction}

Nanostructured films are widely used for surface hardening of cutting tools due to high hardness, good corrosion stability, and low friction coefficient [1-7]. Among these films, NbN-based ones are of increasing interest. Hardness of such binary NbN nitride films is much higher than the bulk material $(H V=14 \mathrm{GPa})$ and higher than other binary nitride films (TiN, ZrN, VN). The hardness of the NbN films deposited by different arc deposition systems reaches 34-49 GPa [8]. The NbN films were also prepared by using magnetron sputtering (MS) [9], ion beam assisted deposition [10], pulsed laser deposition [11]. An increase in hardness was reached by the formation of nanocomposite or nanolayered structures of the films based on niobium nitride. Silicon nitrides are known for their high temperature stability, low friction coefficient and high oxidation resistance. Hence, one can expect that $\mathrm{Nb}-\mathrm{Si}-\mathrm{N}$ nanocomposite and multilayers will combine the properties of the constituent materials and will have improved properties as compared to NbN. Furthermore, we will take into account the films prepared using magnetron sputtering. We reviewed the recent investigations on the $\mathrm{NbN}$ and $\mathrm{Nb}-\mathrm{Si}-\mathrm{N}$ films deposited by magnetron sputtering.

*corresponding author; e-mail: v.rogoz2009@gmail.com
As follows from this brief review, despite the previous investigations of the $\mathrm{NbN}$ and $\mathrm{Nb}-\mathrm{Si}-\mathrm{N}$ films, the comparative study of these two kinds of films prepared with the same deposition parameters has not been carried out yet. Also, so far the effect of the bias voltage supplied to the substrate $\left(U_{s}\right)$ on film properties has not been analyzed.

The aim of this paper was to fill these gaps in the investigations of $\mathrm{NbN}$ and $\mathrm{Nb}-\mathrm{Si}-\mathrm{N}$ films. These films were deposited on silicon wafers at various $U_{s}$. The films were then investigated by: atomic force microscope (AFM), Xray diffraction (XRD), X-ray photoelectron spectroscopy (XPS), nanoindentation, and microindentation. The deposited nanocomposite films were annealed to establish their thermal stability.

\section{Experimental details}

The NbN-based films were deposited on the mirrorpolished Si (100) wafer by dc magnetron sputtering the $\mathrm{Nb}(99.9 \%, \varnothing 72 \times 4 \mathrm{~mm})$ and $\mathrm{Si}(99.999 \%, \varnothing 72 \times 4 \mathrm{~mm})$ targets in an argon-nitrogen atmosphere under the following deposition parameters: substrate temperature $T_{s}=350^{\circ}{ }^{\circ} \mathrm{C}$; substrate bias $U_{s}=0 \mathrm{~V},-20 \mathrm{~V},-40 \mathrm{~V}$, $-70 \mathrm{~V}$; flow rates $F_{\mathrm{Ar}}=40 \mathrm{sccm} ; F_{\mathrm{N}_{2}}=13 \mathrm{sccm}$; working pressure $p_{\mathrm{C}}=0.17 \mathrm{~Pa}$. The current applied to the $\mathrm{Nb}$ target was 150, 200, 250 and $300 \mathrm{~mA}$, which corresponded to a discharge power density $P_{\mathrm{Nb}}$ from $8.5 \mathrm{~W} / \mathrm{cm}^{2}$ to 17.1 $\mathrm{W} / \mathrm{cm}^{2}$. The current on the Si target was $100 \mathrm{~mA}\left(P_{\mathrm{Si}}=\right.$ $\left.5.3 \mathrm{~W} / \mathrm{cm}^{2}\right)$. The base pressure of the vacuum chamber 
was lower than $10^{-4} \mathrm{~Pa}$. The distance between the targets and the substrate holder was $8 \mathrm{~cm}$. The dihedral angle between the target planes was $\sim 45^{\circ}$. The substrates were cleaned ultrasonically before they were put into the vacuum chamber. Also before deposition, the substrates were etched in the vacuum chamber in hydrogen plasma during $5 \mathrm{~min}$. The film deposited at $P_{\mathrm{Nb}}=14.3 \mathrm{~W} / \mathrm{cm}^{2}$ was annealed in a vacuum (0.001 Pa) for 2 hours at 600 , 800 and $1000^{\circ} \mathrm{C}$.

The crystal structure of the films was determined by XRD (diffractometer DRON-3M) using the $\mathrm{CuK}_{\alpha}$ radiation. The crystallite size in films was evaluated from the broadening of peaks in the X-ray diffraction spectra using the Scherrer formula. The chemical bonding status of films was observed by XPS (EC 2401 spectrometer, USSR) using the $\mathrm{MgK}_{\alpha}$ radiation $(E=1253.6 \mathrm{eV})$. The $\mathrm{Au} 4 \mathrm{f}_{7 / 2}$ and $\mathrm{Cu} 2 \mathrm{p}_{3 / 2}$ peaks with binding energies at $84.0 \pm 0.05 \mathrm{eV}$ and $932.66 \pm 0.05 \mathrm{eV}$, respectively, were used as a reference. Surface morphology was analyzed by atomic force microscope (AFM) NanoScope IIIa Dimension 3000 (Digital Instruments, USA). The hardness and elastic modulus of films were determined from the indentation by a Nanoindenter-G200 instrument equipped with a Berkovich pyramidal tip under load in a range of 9$13 \mathrm{mN}$. This range of loads was chosen in order to obtain prominent plastic deformation of film while avoiding the influence of substrate material. The nanohardness $(H)$ and elastic modulus $(E)$ data was obtained from loaddisplacement curves using the Oliver and Pharr method. The Knoop hardness $(H K)$ was estimated by a Microhardness Tester Micromet 2103 BUEHLER Ltd at a loading of $100 \mathrm{mN}$.

\section{Results and discussion}

Figure 1 shows the AFM surface topography of the $\mathrm{NbN}$ and $\mathrm{Nb}-\mathrm{Si}-\mathrm{N}$ films deposited at various $U_{s}$. One can see that the film surface roughness increases with $U_{s}$. Also the surface roughness in the $\mathrm{Nb}-\mathrm{Si}-\mathrm{N}$ films is smaller than in the $\mathrm{NbN}$ ones, which can be due to the availability of the amorphous $\mathrm{SiN}_{x}$ tissue in the $\mathrm{Nb}-\mathrm{Si}-$ $\mathrm{N}$ films (see below). It follows that a decrease in the bias voltage $U_{s}$ and introduction of silicon promote the reduction of surface roughness.

The XRD spectra of the deposited $\mathrm{NbN}$ and $\mathrm{Nb}-\mathrm{Si}-\mathrm{N}$ films are shown in Figs. 2 and 3. The peak A at 35.135.40 and the peak B at 41.1-41.40 can be assigned to the $\delta-\mathrm{NbN}_{x}(111)$ and $\delta-\mathrm{NbN}_{x}(200)$ reflections, respectively. The grain size estimated from the Scherrer formula was 4.1-8.7 $\mathrm{nm}$ and $18.1-19.8 \mathrm{~nm}$ for the $\mathrm{NbN}$ and $\mathrm{Nb}-\mathrm{Si}-\mathrm{N}$ films, respectively. It follows that introduction of Si leads to an increase of $\mathrm{NbN}$ grains.

The results of XPS examination of the as-deposited and annealed $\mathrm{NbN}$ and $\mathrm{Nb}-\mathrm{Si}-\mathrm{N}$ films are presented in Fig. 4. It is known that a native oxide grows on $\mathrm{Nb}$ compounds when exposed to air [12], and the peaks at $204.07 \mathrm{eV}$ and $206.88 \mathrm{eV}$ can be assigned to $\mathrm{Nb} 3 \mathrm{~d}$ in $\mathrm{NbN}(203.97 \mathrm{eV}[13])$ and $\mathrm{Nb}_{2} \mathrm{~N}_{2-x} \mathrm{O}_{3+x}(207.0 \mathrm{eV}[14])$,
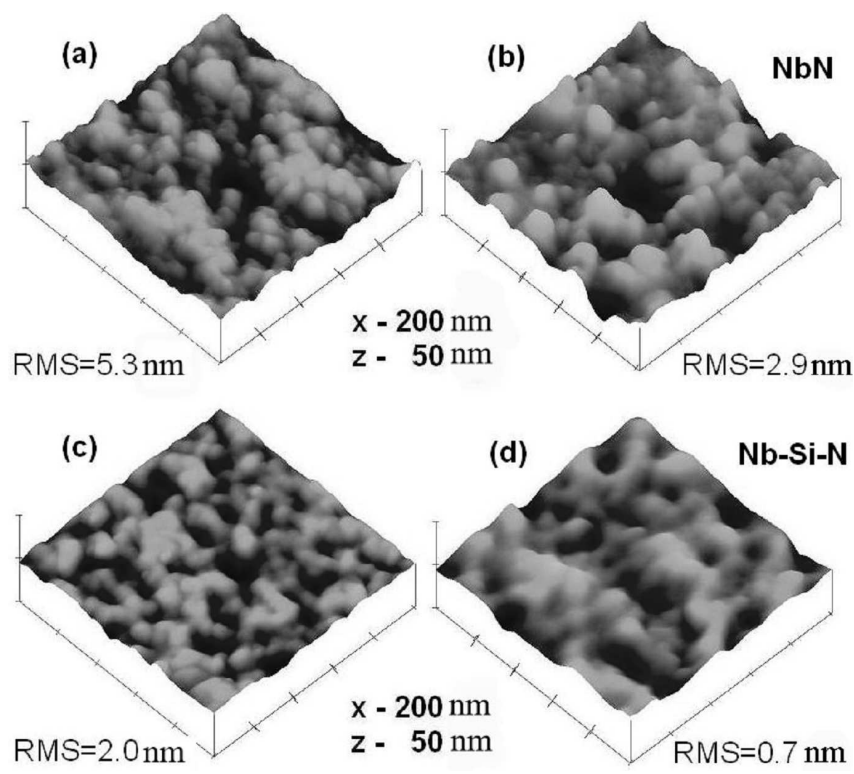

Fig. 1. AFM images of: the $\mathrm{NbN}$ films deposited at $U_{s}=0 \mathrm{~V}(\operatorname{RMS}=5.3 \mathrm{~nm})$ (a) and $U_{s}=-70 \mathrm{~V}$ $(\mathrm{RMS}=2.9 \mathrm{~nm})(\mathrm{b}) ; \mathrm{Nb}-\mathrm{Si}-\mathrm{N}$ films deposited at $U_{s}=0 \mathrm{~V}(\operatorname{RMS}=2.0 \mathrm{~nm})(\mathrm{c})$ and $U_{s}=-70 \mathrm{~V}$ $(\mathrm{RMS}=0.7 \mathrm{~nm})(\mathrm{d})$.

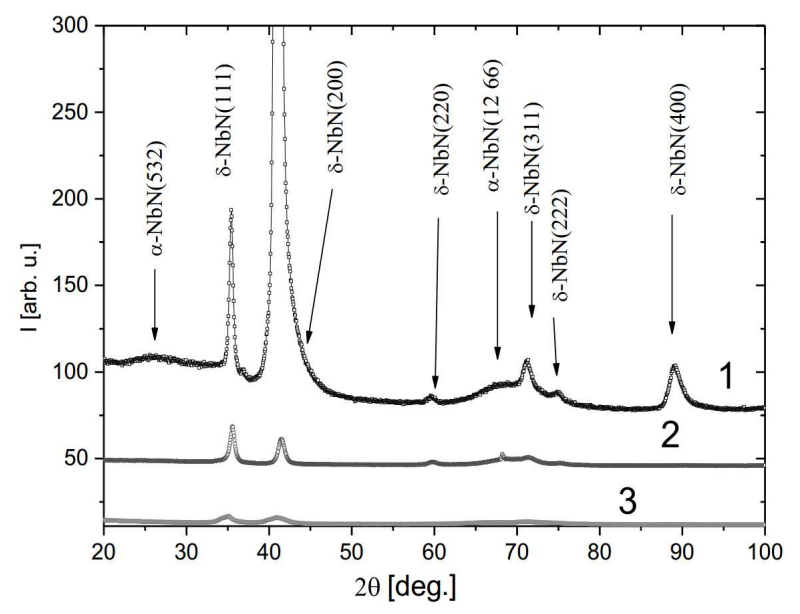

Fig. 2. XRD spectra of NbN films at $U_{s}=0 \mathrm{~V}(1)$, $U_{s}=-40 \mathrm{~V}(2), U_{s}=-70 \mathrm{~V}(3)$.

respectively. For the $\mathrm{NbN}$ films, the peak at $397.4 \mathrm{eV}$ in the $\mathrm{N}$ 1s spectrum is determined by the $\mathrm{Nb}-\mathrm{N}$ bonds, whereas for the $\mathrm{Nb}-\mathrm{Si}-\mathrm{N}$ films, this peak is located around $397.2 \mathrm{eV}$, and can be assigned to $\mathrm{N}$ 1s in $\mathrm{NbN}$ (397.4 eV [12]).

We suppose that the asymmetry of the $\mathrm{N}$ 1s peak can be caused by the $\mathrm{Si}-\mathrm{N}$ bonds in $\mathrm{Si}_{3} \mathrm{~N}_{4}(397.8 \mathrm{eV}$ [14]). The XPS measurements of the Si $2 p$ spectrum provide further information on the $\mathrm{Si}$ bonding in the $\mathrm{Nb}-\mathrm{Si}-\mathrm{N}$ films (cf. Fig. 4). The peak at a binding energy of $101.7 \mathrm{eV}$ is assigned to $\mathrm{Si}$ in $\mathrm{Si}_{3} \mathrm{~N}_{4}$ (101.7 eV [14]), and a shoulder at $103.3 \mathrm{eV}$ in the $\mathrm{Si} 2 \mathrm{p}$ spectrum of the annealed films is supposed to be due to the $\mathrm{Si}-\mathrm{O}$ bonds in $\mathrm{SiO}_{2}$ (103.5 eV [14]). Finally, the O 1s spectra of the NbN 


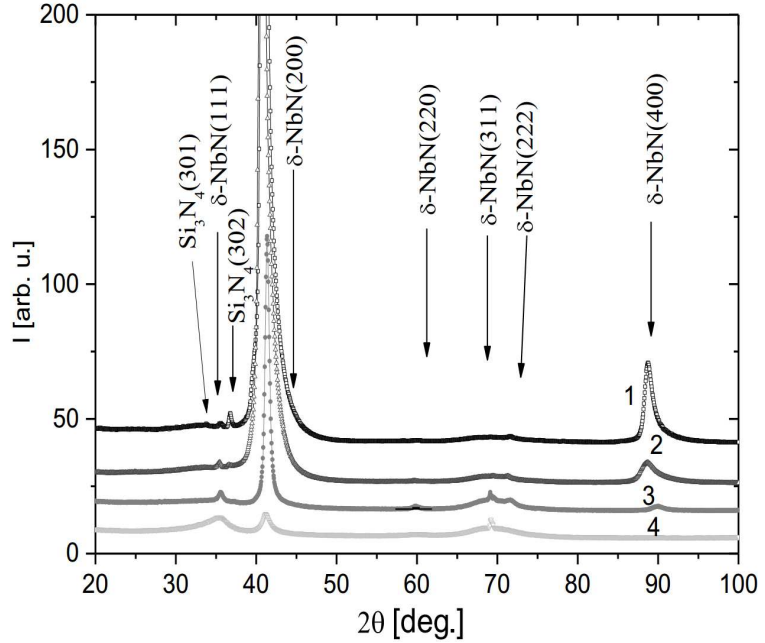

Fig. 3. XRD spectra of $\mathrm{Nb}-\mathrm{Si}-\mathrm{N}$ films at $U_{s}=0 \mathrm{~V}$ $(1), U_{s}=-20 \mathrm{~V}(2), U_{s}=-40 \mathrm{~V}(3), U_{s}=-70 \mathrm{~V}(4)$.
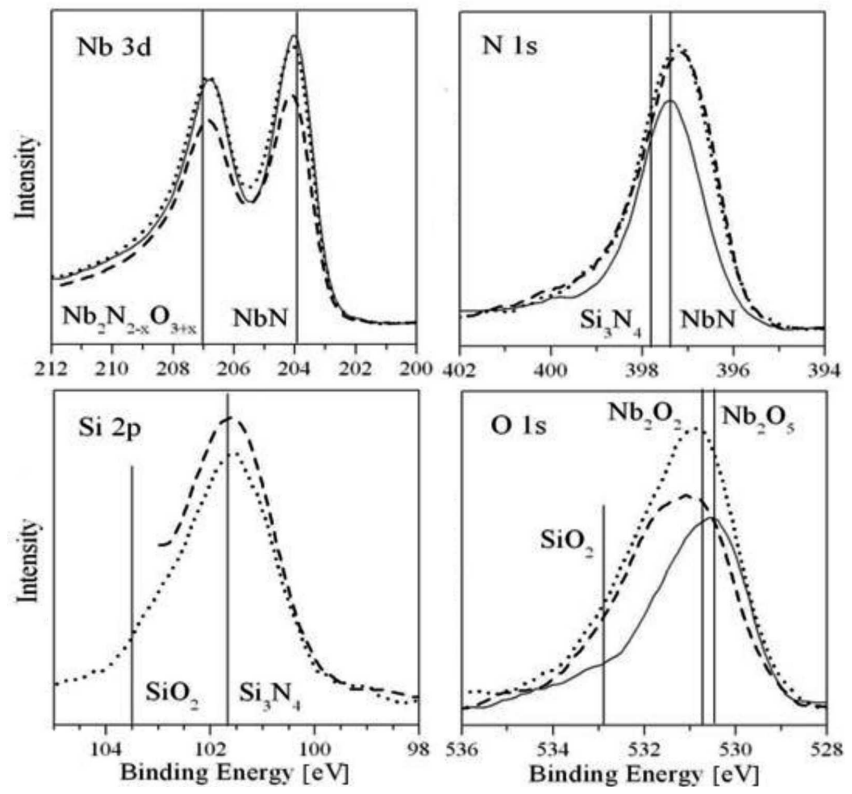

Fig. 4. XPS spectra of the core levels in NbN (solid line), $\mathrm{Nb}-\mathrm{Si}-\mathrm{N}$ (dashed line) and annealed at $1000^{\circ} \mathrm{C}$ $\mathrm{Nb}-\mathrm{Si}-\mathrm{N}$ (dotted line) films deposited at $P_{w}=$ $14.3 \mathrm{~W} / \mathrm{cm}^{2}$. Vertical lines denote the binding energies of the XPS peaks of: $\mathrm{Nb} 3 d$ in NbN, $203.97 \mathrm{eV}$ [13] and $\mathrm{Nb}_{2} \mathrm{~N}_{2-x} \mathrm{O}_{3+x}, 207.0 \mathrm{eV}$ [14]; $\mathrm{N} 1 s$ in $\mathrm{NbN}, 397.4 \mathrm{eV}$ [12] and $\mathrm{Si}_{3} \mathrm{~N}_{4}, 397.8 \mathrm{eV}$ [14]; $\mathrm{Si} 2 p$ in $\mathrm{Si}_{3} \mathrm{~N}_{4}, 101.7 \mathrm{eV}$ and $\mathrm{SiO}_{2}, 103.5 \mathrm{eV}$ [14]; $\mathrm{O} 1 s$ in $\mathrm{Nb}_{2} \mathrm{O}_{5}, 530.4 \mathrm{eV}, \mathrm{Nb}_{2} \mathrm{O}_{2}$, $530.7 \mathrm{eV}$ and $\mathrm{SiO}_{2}, 532.9 \mathrm{eV}[14]$.

and $\mathrm{Nb}-\mathrm{Si}-\mathrm{N}$ films are centered around $530.5 \mathrm{eV}$ and $530.9 \mathrm{eV}$, respectively, and can be attributed to the $\mathrm{Nb}-\mathrm{O}$ bonds in $\mathrm{Nb}_{2} \mathrm{O}_{5}(530.4 \mathrm{eV})$ and $\mathrm{Nb}_{2} \mathrm{O}_{2}(530.7 \mathrm{eV}$ [14]), respectively. In the case of $\mathrm{Nb}-\mathrm{Si}-\mathrm{N}$ films, the $\mathrm{Si}-\mathrm{O}$ bonds in $\mathrm{SiO}_{2}$ can form the wide tail around $532.9 \mathrm{eV}$ [14] (cf. Fig. 4). Using the XPS data (cf. Fig. 4), we estimated the niobium, nitrogen and silicon contents $\left(C_{\mathrm{Nb}}, C_{\mathrm{N}}\right.$ and
$C_{\mathrm{Si}}$, respectively) in the $\mathrm{NbN}$ and $\mathrm{Nb}-\mathrm{Si}-\mathrm{N}$ films. It was found that $C_{\mathrm{Nb}}=44.5$ at. $\%, C_{\mathrm{N}}=55.5$ at. $\%$ for the $\mathrm{NbN}$ films and $C_{\mathrm{Nb}}=45.1$ at. $\%, C_{\mathrm{N}}=43.2$ at. $\%$ and $C_{\mathrm{Si}}=11.7$ at.\% for $\mathrm{Nb}-\mathrm{Si}-\mathrm{N}$ films.

Comparison of the results presented in Figs. 1-4 makes it possible to establish the structure of the $\mathrm{NbN}$ and $\mathrm{Nb}-\mathrm{Si}-\mathrm{N}$ films. The NbN films are nanostructured, and the $\mathrm{Nb}-\mathrm{Si}-\mathrm{N}$ films have a nanocomposite structure, and represent an aggregation of $\delta-\mathrm{NbN}_{x}$ nanocrystallites embedded into the amorphous $\mathrm{Si}_{3} \mathrm{~N}_{4}$ tissue (nc- $\delta$-NbNx/a$\mathrm{Si}_{3} \mathrm{~N}_{4}$ ). In contrast to the $\mathrm{NbN}$ films, the $\mathrm{Nb}-\mathrm{Si}-\mathrm{N}$ ones are textured with the preferable (200) grain orientation. The films contain oxygen in the view of niobium oxides. For the Nb-Si-N films, we also suppose that oxygen forms $\mathrm{SiO}_{2}$ that is segregated along grain boundaries. We note that, despite larger grain sizes, the surface roughness of the $\mathrm{Nb}-\mathrm{Si}-\mathrm{N}$ films is smaller as compared to that of the NbN films. One can assume that the amorphous $\mathrm{SiN}_{4}$ tissue in the nanocomposite $\mathrm{Nb}-\mathrm{Si}-\mathrm{N}$ films smears the relief of the film surface, for this reason, the surface roughness of the nanocomposite films should be lower than that of the NbN films.

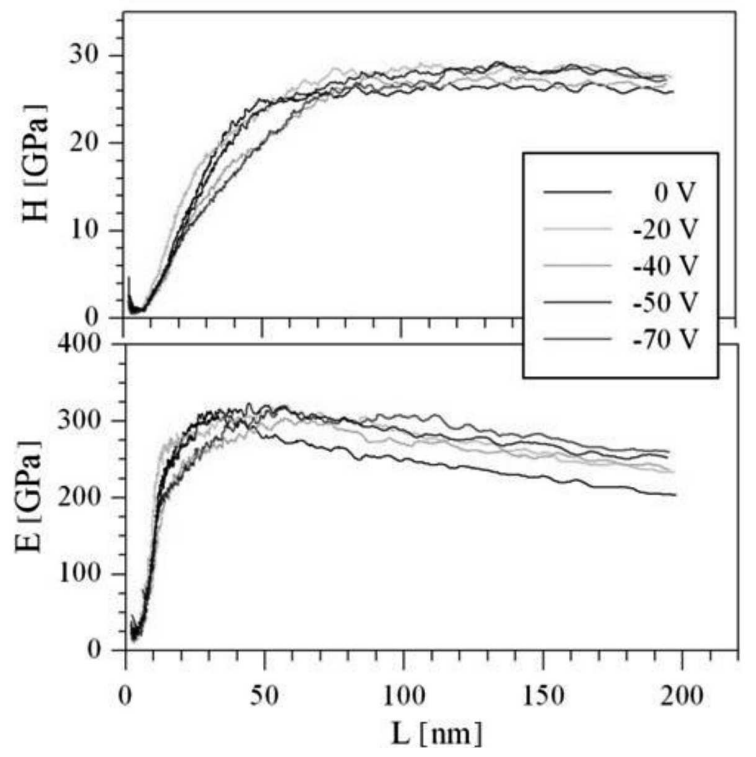

Fig. 5. Dependences of nanohardness $(H)$ and elastic modulus $(E)$ on nanoindenter penetration $(L)$ for the NbN films deposited at various bias voltages.

The dependence of nanohardness $(H)$ and elastic modulus $(E)$ on indenter penetration $(L)$ of the deposited films are presented in Figs 5 and 6 . It can be seen that beginning with $75 \mathrm{~nm}$, the nanohardness practically does not depend on $L$. The elastic modulus decreases upon a reaching maximum values at $L=50 \mathrm{~nm}$. These results point out that the soft silicon substrate does not exert influence on the films nanohardness. The elastic modulus of the films turns out to be more sensitive to the substrates, especially at high $L$. 


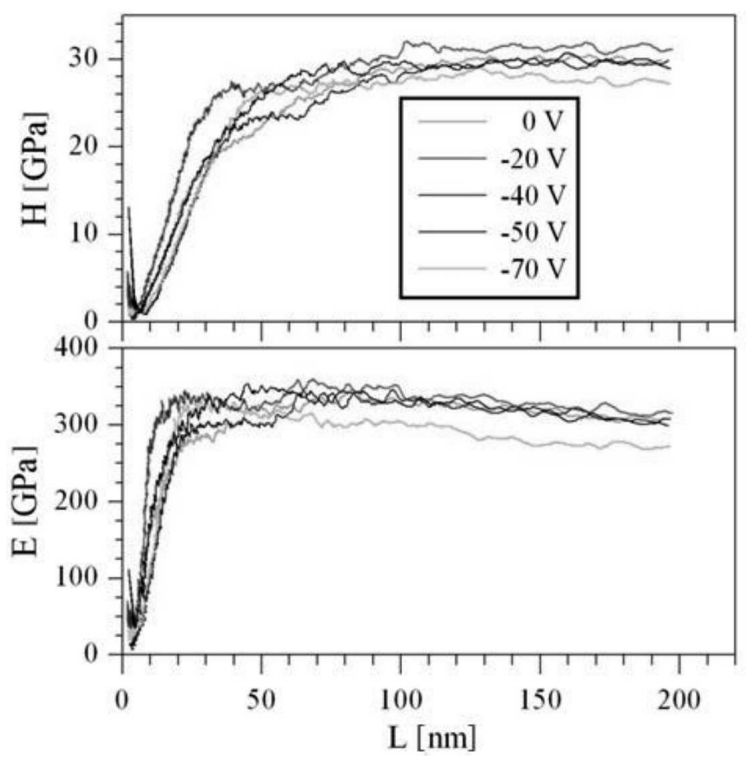

Fig. 6. As Fig. 5 for the $\mathrm{Nb}-\mathrm{Si}-\mathrm{N}$.

\section{Conclusions}

We have deposited the $\mathrm{NbN}$ and $\mathrm{Nb}-\mathrm{Si}-\mathrm{N}$ films on the silicon wafers by magnetron sputtering at various bias voltages applied to the substrate. The comparative investigation of the deposited films was carried out. The AFM investigations show that decrease in the bias voltage and introduction of silicon promote reduction of surface roughness of the films. The XRD and XPS examinations enabled one to establish the possible structure of the deposited films: the NbN films were nanostructured, and the $\mathrm{Nb}-\mathrm{Si}-\mathrm{N}$ ones had a nanocomposite structure, and represented an aggregation of $\delta-\mathrm{NbN}_{x}$ nanocrystallites embedded into the amorphous $\operatorname{SiN}_{x}$ tissue (nc- $\delta$ $\mathrm{NbN}_{x} / \mathrm{a}-\mathrm{Si}_{3} \mathrm{~N}_{4}$ ). In contrast to the $\mathrm{NbN}$ films, the $\mathrm{Nb}-$ $\mathrm{Si}-\mathrm{N}$ ones are textured with the preferable (200) grain orientation. The $\mathrm{Nb}-\mathrm{Si}-\mathrm{N}$ films exhibit higher hardness $(H \approx 30 \mathrm{GPa}, H K \approx 44 \mathrm{GPa})$ than the $\mathrm{NbN}$ films $(H \approx 28 \mathrm{GPa}, H K \approx 36 \mathrm{GPa})$ mainly due to the formation of the nanocomposite nc- $\delta-\mathrm{NbN}_{x} / \mathrm{a}-\mathrm{Si}_{3} \mathrm{~N}_{4}$ structure. The elastic modulus of the $\mathrm{NbN}$ and $\mathrm{Nb}-\mathrm{Si}-\mathrm{N}$ films increases with the increasing grain sizes.

\section{References}

[1] A.D. Pogrebnjak, A.G. Ponomarev, A.P. Shpak, Phys. Usp. 55, 270 (2012).

[2] A.D. Pogrebnjak, V.M. Beresnev, Nanocoatings, Nanosystems, Nanotechnologies, Bentham Sci. Pub., Sharjah 2012.

[3] A.D. Pogrebnjak, V. M. Beresnev, A. A. Demianenko, Phys. Solid State. 54, 1882 (2012).

[4] R. Krause-Rehberg, A.D. Pogrebnyak, O.V. Sobol', Phys. of Metals and Metallogr. 114, 672 (2013).

[5] A.D. Pogrebnjak, Yu.A. Kravchenko, S.B. Kislitsyn, Surface and Coatings Technology 201, 2621 (2006).

[6] A.D. Pogrebnjak, S. Bratushka, V.I. Boyko, Nucl. Instr. Meth. 145, 373 (1998).

[7] A.D. Pogrebnjak, A.D. Mikhaliov, A.D., N.A. Pogrebnjak, Phys. Let. 241, 357 (1998).

[8] V.N. Zhytomirsky, Surf. Coat. Technol. 201, 6122 (2007).

[9] G.A. Fontalvo, V. Terziyska, C. Mitterer, Surf. Coat. Technol. 202, 1017 (2007).

[10] N. Hayashi, I.H. Murzin, I. Sakamoto, M. Ohkubo Thin Solid Films 259, 146 (1995).

[11] G. Cappuccio, U. Gambardella, A. Morone, S. Orlando, G.P. Patisi, Appl. Surf. Sci. 109, 399 (1997).

[12] J. Wang, Z. Song, K. Xu, Surf. Coat. Technol. 201, 4931 (2007).

[13] J.J. Jeong, C.M. Lee, Appl. Surf. Sci. 214, 11 (2003).

[14] G. Beamson, D. Briggs, High Resolution XPS of Organic Polymers, The Scienta ESCA300 Database, Wiley Interscience 1992. 